\title{
ULUSLARARASI HİSSE SENEDİ PİYASALARINDA ÖZYİNELEMELİ ESNEK TAHMİNLEME İLE ÇOKLU BALONLARIN BELİRLENMESİ
}

\author{
Efe Cağlar ÇAĞLI* ve Pınar EVRİM MANDACI**
}

öz

Bu çalışmada, birçok gelişmiş ve gelişmekte olan hisse senedi piyasalarındaki çoklu rasyonel balonlar incelenmeye çalışılmışır. Ocak 2002- Nisan 2017 dönemi için 39 hisse senedi piyasalarının aylık kâr payı getirilerine genelleştirilmiş eküs genişletilmiş Dickey Fuller (GSADF) testi kullanılmıştır. Bu ekonometrik çerçeve çoklu rasyonel balonların tarihlerini saptamaya izin vermekte ve dahası özyinelemeli esnek tahminleme aracılığı ile standart birim kök testlerinin üzerinde bir performans göstermektedir. Çalışmanın ampirik sonuçları ele alınan ülke piyasalarının çoğunda rasyonel balonların varlığı güçlü bir biçimde kanıtlamaktadır. Son olarak, hisse senedi piyasalarındaki rasyonel balonların 2007-08 global finansal kriz dönemi etrafında olduğu bulunmuştur.

Anahtar Sözcükler: Rasyonel Balonlar, Hisse Senedi Piyasası, Global Finansal Kriz, Özyinelemeli Esnek Tahminleme

\section{DETECTING MULTIPLE BUBBLES IN INTERNATIONAL STOCK MARKETS WITH RECURSIVE FLEXIBLE WINDOWS}

\section{ABSTRACT}

In this paper, we try to examine the multiple rational bubbles in several developed and emerging stock markets. We employ the generalized sup augmented Dickey-Fuller (GSADF) test on the monthly dividend yield series of 39 stock markets for the period from January 2002 to April 2017. This econometric framework allows us to date-stamp the multiple rational bubbles and furthermore outperforms the standard unit root 8.5 tests through its recursive flexible estimation window. The empirical results strongly confirm the existence of rational bubbles in most of the analyzed stock markets. Finally, it was found out that the rational bubbles in the stock markets occurred around the 2007-08 global financial turmoil.

Keywords: Rational Bubbles, Stock Market, Global Financial Crisis, Recursive Flexible Window

* Dokuz Eylül Üniversitesi, İşletme Fakültesi, İşletme Bölümü, İzmir, E-posta: efe.cagli@deu.edu.tr

** Dokuz Eylül Üniversitesi, İşletme Fakültesi, İşletme Bölümü, İzmir, E-posta: pinar.evrim@deu.edu.tr 


\section{Detecting Multiple Bubbles in International Stock Markets with Recursive Flexible Windows}

\section{INTRODUCTION}

"Bubble" is defined as the divergence of an asset's actual price from its fundamental value. In an efficient market, stock price is equal to its fundamental value that is the sum of the present value of its expected dividends. Any divergence will indicate inefficiency or irrational bubbles. However, the literature on bubbles conclude that the bubbles can be rational if the investor rationally expects an increase in the future price and considers it in valuation. As a result, stock price will include two components, i.e., its fundamental value and the rational bubble.

Theoretical formation of the bubbles is elaborated in some studies such as those of Flood and Garber (1980), Blanchard and Watson (1982), Obstfeld and Rogoff (1985) and West (1987). Rational bubble theory states that the investors act rationally by boosting prices since they solemnly believe that the stock's price will increase further, the bubble will continue to grow and they will get high returns which will enable them to compensate the losses in case of a possible market crash (see Chan, McQueen and Thorley, 1998). According to Blanchard (1979) the rational bubbles may mold into such a special shape that a rapid increase in prices without a justified fundamental information is followed either by a burst or a sharp decline. Santoni (1987) characterizes bubbles as persistent, systematic, and he underlines that they exhibit increasing price deviations from their fundamental values.

The existence of bubbles reduces the linear relationship between price and dividends. The cointegration between the prices and dividends signifies the absence of bubbles. Campbell and Shiller (1988) argue that if dividend growth and the discount factor are stationary series, the log dividend yield should be stationary in the absence of rational bubbles just as in the existence of cointegration between the prices and dividends. Therefore, unit root tests can also be employed to investigate whether the log dividend yield series are stationary. The existence of unit root in the log dividend yield series will indicate bubbles.

Most of the earlier studies investigating bubbles have used standard unit root tests, such as augmented Dickey-Fuller (1979) (ADF), Phillips and Perron (1988). Among them, Diba and Grossman (1988), Craine (1993), Lamont (1998) have found supportive evidence for the existence of bubbles. However, Evans (1991) argues that the standard tests cannot detect collapsing bubbles and may lead to unreliable results. Subsequent studies have attempted to examine the issue empirically by 


\section{Efe Cağlar ÇAĞLI ve Pınar EVRIM MANDACI}

proposing additional bubble tests; however, Gürkaynak (2008) argues that many existing standard econometric tests encounter difficulties in detecting rational bubbles.

The reliability of the studies on rational bubbles depends heavily on the advances in the econometric techniques. Phillips, Wu and $\mathrm{Yu}$ (2011) proposes a test procedure which overcomes the shortcomings of previous ex-post econometric frameworks. They extend the standard Augmented Dickey-Fuller (ADF) unit root test by proposing a recursive test procedure by which one can calculate right-tailed sup ADF (SADF) test. This sequential test procedure is designed to enable policy regulators to date-stamp the emergence of speculative bubbles and offers a potential tool for real-time detection of stock market bubbles. Homm and Breitung (2012) confirms that SADF test outperforms all other standard tests in the Monte Carlo simulations and detects rational bubbles accurately. More recently, Phillips, Shi and Yu (2015) propose the generalized SADF (GSADF) test procedure which allows researchers to date-stamp the multiple rational bubbles more successfully than do the standard unit root tests, thanks to its recursive flexible estimation window. The main difference between SADF and GSADF is that the latter allows changing not only the end-dates but also the start dates within a feasible range (Phillips et al. 2015). Thus, their flexible ex-ante test procedure goes far beyond the previous ex-post bubble tests.

This paper contributes to the literature on bubbles in two ways. Firstly, it employs GSADF test that can overcome most of the criticisms related to the bubble tests with standard unit root tests. Secondly, it is comparatively more comprehensive study in terms of the number of the analyzed stock markets it covers -thirty-nine major stock markets and the emerging markets, which represent almost the overall structure. Hence, it enables us to make comparison between them. Our result supports the existence of this phenomenon in all countries with the exceptions of Brazil, Chile, India, and South Korea. The rest of this paper is organized as follows: In Section 2 we present the methodology. In Section 3, we present empirical application. and Section 4 concludes the paper.

\section{ECONOMETRIC METHODOLOGY}

Phillips et al.'s (2015) econometric framework is based on the following regression which uses recursive flexible windows: 


\section{Detecting Multiple Bubbles in International Stock Markets with} Recursive Flexible Windows

$$
\Delta y_{t}=\hat{\alpha}_{r_{1}, r_{2}}+\hat{\beta}_{r_{1}, r_{2}} y_{t-1}+\sum_{i=1}^{k} \hat{\psi}_{r_{1}, r_{2}}^{i} \Delta y_{t-i}+\hat{\varepsilon}_{t}
$$

where $k$ is the lag length; and $r_{1}$ and $r_{2}$ are the start and end dates of the regression, respectively; and the whole sample interval is defined as [0, 1]. The standard ADF statistic can be calculated as:

$$
A D F_{r_{1}, r_{2}}=\beta_{r_{1}, r_{2}} / \operatorname{se}\left(\beta_{r_{1}, r_{2}}\right)
$$

We can calculate GSADF test statistic by obtaining right-tailed ADF tests from the regressions of which start dates $\left(r_{1}\right)$ are varying from 0 to $r_{2}-r_{0}$ and end dates are varying from $r_{0}$ to 1 :

$$
\operatorname{GSADF}\left(r_{0}\right)=\sup _{\substack{r_{2} \in\left[\mathrm{r}_{0}, 1\right] \\ \mathrm{r}_{1} \in\left[0, r_{2}-r_{0}\right]}}\left\{A D F_{r_{1}}^{r_{2}}\right\}
$$

To detect the explosiveness periods, Phillips et al. (2015) suggest backward SADF (BSADF) test sequence which can be obtained by calculating the right-tailed ADF tests on the backward expanding subsamples of which the start date $\left(r_{1}\right)$ is varying from 0 to $r_{2}-r_{0}$ and the end date $\left(r_{2}\right)$ is fixed. BSADF test statistic can be written as follows:

$$
B S A D F_{r_{2}}\left(r_{0}\right)=\sup _{\mathrm{r}_{1} \in\left[0, r_{2}-r_{0}\right]}\left\{A D F_{r_{1}}^{r_{2}}\right\}
$$

By comparing BSADF statistic sequence with the right-tailed critical values (CV) obtained from Monte Carlo simulations, we can define the origination and termination dates of the bubbles:

$$
\begin{aligned}
& \hat{r}_{e}=\inf _{r_{2} \in\left[r_{0}, 1\right]}\left\{r_{2}: B S A D F_{r_{2}}>c v_{r_{2}}^{\beta_{T}}\right\} \\
& \hat{r}_{f}=\inf _{r_{2} \in\left[\hat{r}_{e}+\delta \log (T) / T, 1\right]}\left\{r_{2}: B S A D F_{r_{2}}<c v_{r_{2}}^{\beta_{T}}\right\}
\end{aligned}
$$

where $T$ is the sample size; $c v_{r_{2}}^{\beta_{T}}$ is the $100\left(1-\beta_{T}\right) \%$ critical value of ADF statistic based on $\left[T r_{2}\right]$ observations.

\section{DATA AND EMPIRICAL RESULTS}

We analyze the monthly dividend yield series of thirty-nine (39) stock markets. The data are obtained from the FactSet and cover the 


\section{Efe Cağlar ÇAĞLI ve Pınar EVRIM MANDACI}

period between January 2002 and April 2017. We estimate the GSADF statistics for each stock market's dividend yield series and report the results in Table 1. The most of the GSADF statistics are calculated higher than the critical value for the statistical significance level of $1 \%$. The empirical results suggest the existence of rational bubbles in all the stock markets except Brazil, Chile, India, and South Korea. It is noteworthy that the rational bubbles are present in all the developed markets of which GSADF statistics are generally calculated higher than that of emerging markets.

Table 1: GSADF Test Statistics

\begin{tabular}{|c|c|c|c|c|c|}
\hline Country & GSADF & Country & GSADF & Country & GSADF \\
\hline Australia & $3.7440^{\mathrm{a}}$ & Hungary & $3.2212^{\mathrm{a}}$ & Portugal & $1.9773^{\mathrm{c}}$ \\
\hline Austria & $7.2778^{\mathrm{a}}$ & India & 1.3035 & Russia & $\begin{array}{c}10.2413 \\
\mathrm{a}\end{array}$ \\
\hline Belgium & $6.4453^{\mathrm{a}}$ & Indonesia & $2.8809^{\mathrm{a}}$ & Singapore & $5.0831^{\mathrm{a}}$ \\
\hline Brazil & 1.2518 & Israel & $2.5432^{\mathrm{b}}$ & South Africa & $2.9142^{\mathrm{a}}$ \\
\hline Canada & $6.2869^{\mathrm{a}}$ & Italy & $4.2098^{\mathrm{a}}$ & South Korea & 1.6453 \\
\hline Chile & 0.1312 & Japan & $5.8602^{\mathrm{a}}$ & Spain & $7.3365^{\mathrm{a}}$ \\
\hline $\begin{array}{c}\text { Czech } \\
\text { Republic }\end{array}$ & $3.5552^{\mathrm{a}}$ & Luxembourg & $5.3583^{\mathrm{a}}$ & Sweden & $4.1587^{\mathrm{a}}$ \\
\hline Denmark & $2.7463^{\mathrm{a}}$ & Malaysia & $2.4914^{\mathrm{b}}$ & Switzerland & $4.3421^{\mathrm{a}}$ \\
\hline Finland & $5.5501^{\mathrm{a}}$ & Mexico & $2.2279^{\mathrm{b}}$ & Taiwan & $2.7795^{\mathrm{a}}$ \\
\hline France & $5.5319^{\mathrm{a}}$ & Netherlands & $3.4979^{\mathrm{a}}$ & Thailand & $2.0349^{\mathrm{c}}$ \\
\hline Germany & $4.2303^{\mathrm{a}}$ & Norway & $3.6023^{\mathrm{a}}$ & Turkey & $2.8060^{\mathrm{a}}$ \\
\hline Greece & $5.5917^{\mathrm{a}}$ & Philippines & $4.5558^{\mathrm{a}}$ & $\begin{array}{c}\text { United } \\
\text { Kingdom }\end{array}$ & $6.3533^{\mathrm{a}}$ \\
\hline Hong Kong & $2.8022^{\mathrm{a}}$ & Poland & $4.0205^{\mathrm{a}}$ & United States & $7.5158^{\mathrm{a}}$ \\
\hline
\end{tabular}

Note: GSADF is the generalized sup augmented Dickey-Fuller statistic. Critical values for the GSADF tests are $1.8607,2.0948$, and 2.6507 for the statistical significance levels of $10 \%$, $5 \%$, and $1 \%$, respectively. The critical values are obtained from Monte Carlo simulation with 2,000 replications (the sample size is 184). Superscripts $a, b$, and $c$ depict that the GSADF test statistics are statistically significant at $1 \%, 5 \%$, and $10 \%$, respectively.

Since we have found that most of the stock markets experience rational bubbles, we obtain BSADF statistics sequence to date stamp the origination and the termination of the bubbles. BSADF statistics sequences for each stock market along with the $99 \%$ critical values (CV) sequences are demonstrated in Figure 1. It is clear from the BSADF and $\mathrm{CV}$ sequences that the common bubble date for the analyzed stock markets is around the 2007-2008 global financial crises. 
Detecting Multiple Bubbles in International Stock Markets with Recursive Flexible Windows
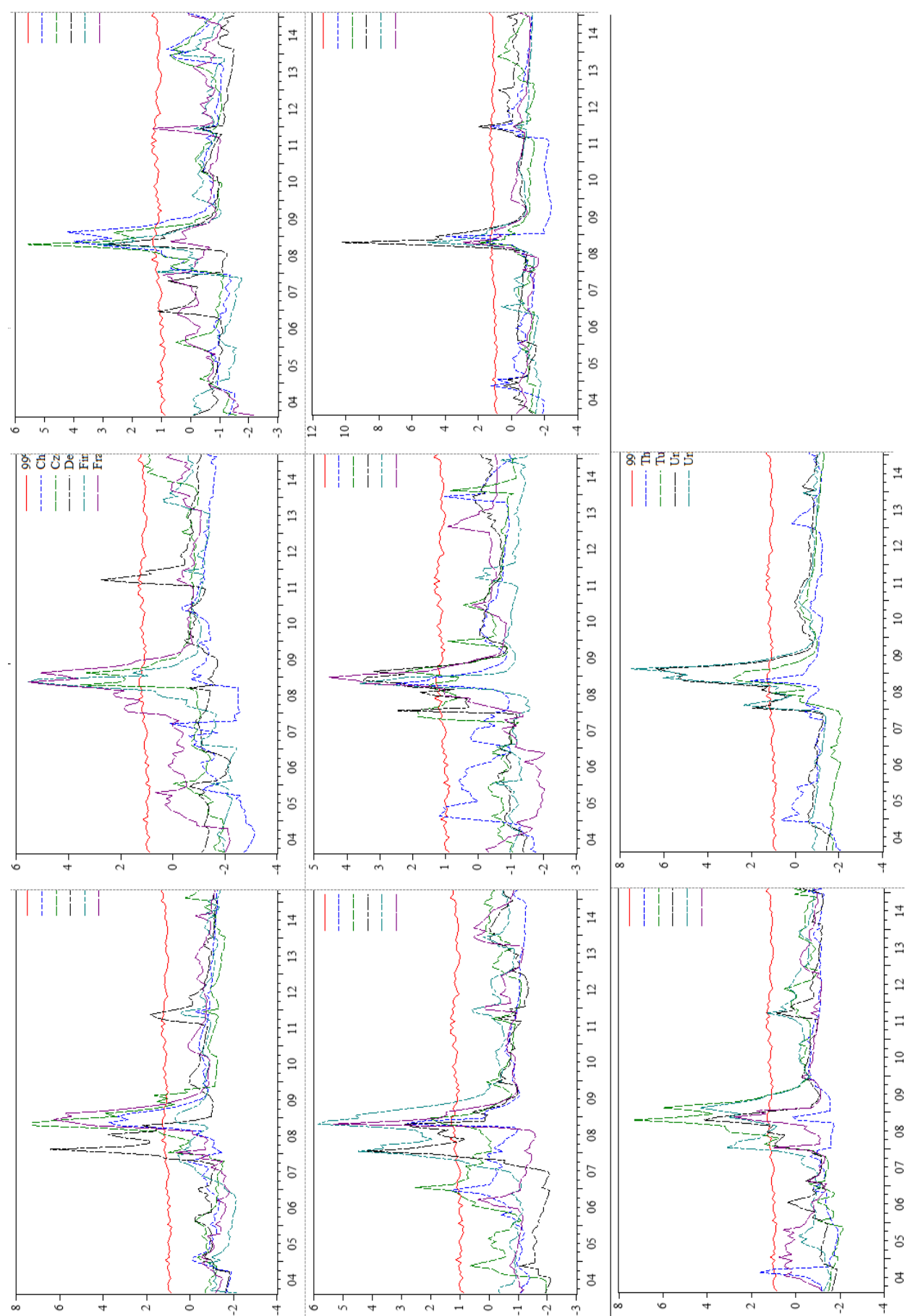

Figure 1: BSADF and CV Sequences 


\section{Efe Cağlar ÇAĞLI ve Pınar EVRIM MANDACI \\ CONCLUSION}

This paper examines the existence of rational bubbles in thirty-nine stock markets by employing an ex-ante test procedure that overcomes the shortcomings of the standard bubble tests. Our results show the existence of rational bubbles in all markets except Brazil, Chile, India, and South Korea stock markets. It is important to stress that it is possible to run into rational bubble bursts in all the major stock markets with attractive investment environments in terms of liquidity, breadth and depth. On the other hand, the stock markets where rational bubbles could not be diagnosed are from the group of emerging economies. Future research can be on determining the fundamental and/or speculative factors that increase the possibility of rational bubble occurrence in those markets, particularly in the emerging markets that are rarely analyzed.

\section{REFERENCES}

Blanchard, O.J. (1979). Speculative Bubbles, Crashes and Rational Expectations. Economics Letters, 3(4), 387-389.

Blanchard, O.J. and Watson M.W. (1982). Bubbles, Rational Expectations and Financial Markets." P. Wachtel (Ed.), Crises in the Economic and Financial Structure, Lexington, MA: D.C. Heathand Company.

Campbell, J.Y., and Shiller, R.J. (1988). The Dividend-Price Ratio and Expectations of Future Dividends and Discount Factors. Review of Financial Studies, 1(3), 195-228.

Chan, K., McQueen, G., and Thorley, S. (1998). Are There Rational Speculative Bubbles in Asian Stock Markets? Pacific-Basin Finance Journal, 6(1), 125-151.

Craine, R. (1993). Rational Bubbles. Journal of Economic Dynamics and Control, 17(5-6), 829-846.

Diba, B.T., and Grossman, H.I. (1988). The Theory of Rational Bubbles in Stock Prices. The Economic Journal, 98(392), 746-754.

Dickey, D.A., and Fuller, W.A. (1979). Distribution of the Estimators for Autoregressive Time Series with a Unit Root. Journal of the American Statistical Association, 74(366), 427-431.

Evans, G.W. (1991). Pitfalls in Testing for Explosive Bubbles in Asset Prices. American Economic Review, 81(4), 922-930. 


\section{Detecting Multiple Bubbles in International Stock Markets with Recursive Flexible Windows}

Flood, R.P., and Garber, P.M. (1980). Market Fundamentals versus PriceLevel Bubbles: The First Tests. The Journal of Political Economy, $88(4), 745-770$.

Gürkaynak, R.S. (2008). Econometric Tests of Asset Price Bubbles: Taking Stock. Journal of Economic Surveys, 22(1), 166-186.

Homm, U., and Breitung, J. (2012). Testing for Speculative Bubbles in Stock Markets: A Comparison of Alternative Methods. Journal of Financial Econometrics, 10(1), 198-231.

Lamont, O. (1998). Earnings and Expected Returns. Journal of Finance, 53(5), 1563-1587.

Obstfeld, M., and Rogoff, K. (1987). Ruling Out Nonstationary Speculative Bubbles. National Bureau of Economic Research Working Paper Series, No. 1601.

Phillips, P.C.B., Shi, S., and Yu, J. (2015). Testing for Multiple Bubbles: Historical Episodes of Exuberance and Collapse in the S\&P 500. International Economic Review, 56(4), 1043-1078.

Phillips, P.C.B., Wu, Y., and Yu, J. (2011). Explosive Behavior In The 1990S Nasdaq: When Did Exuberance Escalate Asset Values? International Economic Review, 52(1), 201-226.

Phillips, P. C., and Perron, P. (1988). Testing for a unit root in time series regression. Biometrika, 75(2), 335-346.

Santoni, G.J. (1987). The Great Bull Markets 1924-29 And 1982-87: Speculative Bubbles or Economic Fundamentals? Federal Reserve Bank of St. Louis Review, 1 (1) 16-30.

West, K. D. (1987). A Specification Test for Speculative Bubbles. The Quarterly Journal of Economics, 102(3), 553-580. 